Prepared in cooperation with the U.S. Army Corps of Engineers

\title{
An Assessment of Two Methods for Identifying Undocumented Levees Using Remotely Sensed Data
}

Scientific Investigations Report 2015-5009 



\section{An Assessment of Two Methods for Identifying Undocumented Levees Using Remotely Sensed Data}

By Christiana Czuba, Byron Williams, Jack Westman, and Keith LeClaire

Prepared in cooperation with the U.S. Army Corps of Engineers

Scientific Investigations Report 2015-5009 


\title{
U.S. Department of the Interior SALLY JEWELL, Secretary
}

\section{U.S. Geological Survey Suzette M. Kimball, Acting Director}

\author{
U.S. Geological Survey, Reston, Virginia: 2015
}

For more information on the USGS - the Federal source for science about the Earth, its natural and living resources, natural hazards, and the environment—visit http://www.usgs.gov or call 1-888-ASK-USGS.

For an overview of USGS information products, including maps, imagery, and publications, visit http://www.usgs.gov/pubprod/.

Any use of trade, firm, or product names is for descriptive purposes only and does not imply endorsement by the U.S. Government.

Although this information product, for the most part, is in the public domain, it also may contain copyrighted materials as noted in the text. Permission to reproduce copyrighted items must be secured from the copyright owner.

Suggested citation:

Czuba, Christiana, Williams, Byron, Westman, Jack, and LeClaire, Keith, 2015, An assessment of two methods for identifying undocumented levees using remotely sensed data: U.S. Geological Survey Scientific Investigations Report 2015-5009, 19 p., http://dx.doi.org/10.3133/sir20155009.

ISSN 2328-0328 (online) 


\section{Acknowledgments}

The authors wish to thank the U.S. Army Corps of Engineers for their cooperation in this study and for the project coordination provided by Terry Zien. Jennifer Nelson, the State Hazard Mitigation Officer at Minnesota Homeland Security and Emergency Management, along with other members of the Minnesota Silver Jackets Hazard Mitigation Team, are acknowledged for supporting this study. Local knowledge of the river and levee management was provided for Delano, Minnesota, by Robert Van Lith (Fire Chief, city of Delano) and by Paul Swearengin (city of Delano Public Works Department); and for Springfield, Minnesota, by Scott Johnson (Emergency Manager and Utilities Superintendent, city of Springfield) and by Shaun Luker (Bolton and Menk, Inc.). Jonathan Czuba of the University of Minnesota is thanked for sharing his MATLAB ${ }^{\circledR}$ expertise. 



\section{Contents}

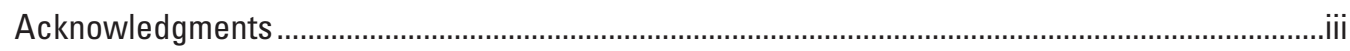

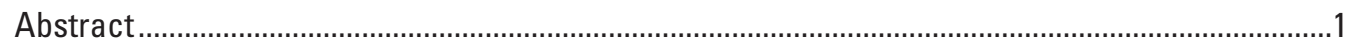

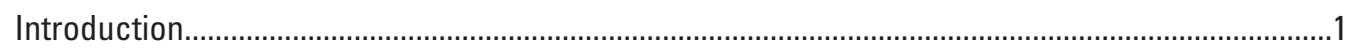

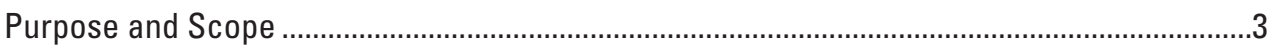

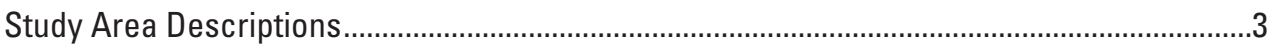

South Fork Crow River at Delano, Minnesota ................................................................

Cottonwood River at Springfield, Minnesota ………………............................................

Two Methods for Identifying Undocumented Levees Using Remotely Sensed Data.........................

Hillshade Method and Site Visit Verification.............................................................................

Wavelet-Transform Method ……………………………….............................................

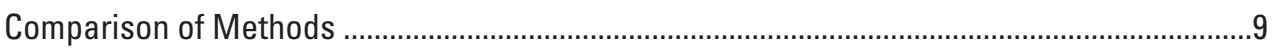

Assessment of the Methods Used to Identify Undocumented Levees...........................................13

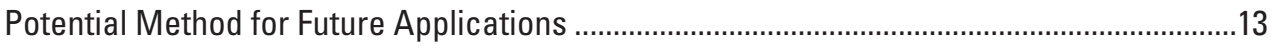

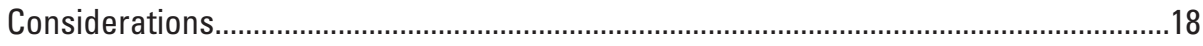

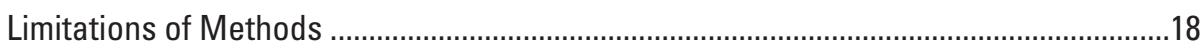

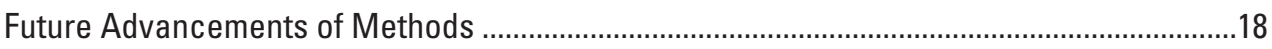

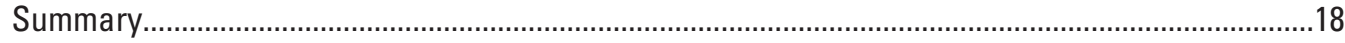

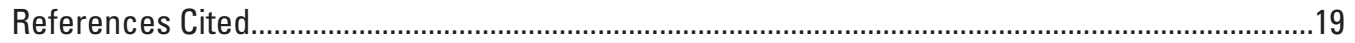

\section{Figures}

1. Maps showing location of study areas for the cities of Delano on the South Fork Crow River and Springfield on the Cottonwood River, Minnesota ......................................

2. Schematic showing measured dimensions of levees .....................................................5

3. Map showing potential levees identified using the hillshade method and field visits, Delano, Minnesota, 2013 .......................................................................................

4. Photographs showing levees assessed in the field by the U.S. Army Corps of Engineers, July 18, 2013, Delano, Minnesota ................................................................7

5. Graph showing Mexican hat wavelet as a function of distance, scale parameter, and location parameter

6. Maps showing wavelet-transform coefficients for selected combinations of wavelet-scale parameter and output-filter threshold, with thresholds at selected percentiles of the distribution of coefficients, Springfield, Minnesota...

7. Maps showing wavelet-transform coefficients for selected combinations of wavelet-scale parameter and output-filter threshold, with thresholds at selected percentiles of the distribution of coefficients, Delano, Minnesota

8. Maps showing comparison of potential levees identified by two methods, Delano, Minnesota 


\section{Tables}

1. Ten highest historical flood wave crests through $\mathbf{2 0 1 4}$ for the South Fork Crow River at Delano, Bridge Avenue streamgage, Minnesota.

2. Ten highest historical flood wave crests through 2014 for the Cottonwood River near Springfield, CR2 streamgage, Minnesota ......................................................................

3. Summary of dimensions of assessed potential levees, Delano, Minnesota, 2013 ............6

4. Summary of dimensions of assessed potential levees, Springfield, Minnesota, 2013 ...13

\section{Conversion Factors}

International System of Units to Inch/Pound

\begin{tabular}{|c|c|c|}
\hline Multiply & By & To obtain \\
\hline \multicolumn{3}{|c|}{ Length } \\
\hline meter (m) & 3.281 & foot $(f t)$ \\
\hline
\end{tabular}

Inch/Pound to International System of Units

\begin{tabular}{lccc}
\hline & Multiply & By & To obtain \\
\hline foot $(\mathrm{ft})$ & Length & meter $(\mathrm{m})$ \\
\hline
\end{tabular}

\section{Datum}

Vertical coordinate information is referenced to the North American Vertical Datum of 1988 (NAVD 88).

Horizontal coordinate information is referenced to the North American Datum of 1983 (NAD 83).

Elevation, as used in this report, refers to distance above the vertical datum. 


\section{Abbreviations}

$\begin{array}{ll}\text { AHPS } & \text { Advanced Hydrologic Prediction Service } \\ \text { DEM } & \text { digital elevation model } \\ \text { GIS } & \text { geographic information system } \\ \text { GPS } & \text { global positioning system } \\ \text { lidar } & \text { light detection and ranging } \\ \text { MNDNR } & \text { Minnesota Department of Natural Resources } \\ \text { NAD 83 } & \text { North American Datum of 1983 } \\ \text { NAVD 88 } & \text { North American Vertical Datum of } 1988 \\ \text { NLD } & \text { National Levee Database } \\ \text { NWS } & \text { National Weather Service } \\ \text { USACE } & \text { U.S. Army Corps of Engineers } \\ \text { USGS } & \text { U.S. Geological Survey }\end{array}$





\title{
An Assessment of Two Methods for Identifying Undocumented Levees Using Remotely Sensed Data
}

\author{
By Christiana Czuba, ${ }^{1}$ Byron Williams, ${ }^{2}$ Jack Westman, ${ }^{2}$ and Keith LeClaire ${ }^{2}$
}

\section{Abstract}

Many undocumented and commonly unmaintained levees exist in the landscape complicating flood forecasting, risk management, and emergency response. This report describes a pilot study completed by the U.S. Geological Survey in cooperation with the U.S. Army Corps of Engineers to assess two methods to identify undocumented levees by using remotely sensed, high-resolution topographic data. For the first method, the U.S. Army Corps of Engineers examined hillshades computed from a digital elevation model that was derived from light detection and ranging (lidar) to visually identify potential levees and then used detailed site visits to assess the validity of the identifications. For the second method, the U.S. Geological Survey applied a wavelet transform to a lidar-derived digital elevation model to identify potential levees. The hillshade method was applied to Delano, Minnesota, and the wavelet-transform method was applied to Delano and Springfield, Minnesota. Both methods were successful in identifying levees but also identified other features that required interpretation to differentiate from levees such as constructed barriers, high banks, and bluffs. Both methods are complementary to each other, and a potential conjunctive method for testing in the future includes (1) use of the wavelet-transform method to rapidly identify slope-break features in high-resolution topographic data, (2) further examination of topographic data using hillshades and aerial photographs to classify features and map potential levees, and (3) a verification check of each identified potential levee with local officials and field visits.

\section{Introduction}

Local, State, and Federal managers that are tasked with forecasting flood peaks, predicting the extent of flood inundation, mitigating the risk associated with flooding or levee failure, and responding during flood emergencies require detailed knowledge about locations and characteristics of

\footnotetext{
${ }^{1}$ U.S. Geological Survey.

${ }^{2}$ U.S. Army Corps of Engineers, Saint Paul District.
}

land features that affect the flow of water along a river. An example of a land feature is an artificial levee. An artificial levee is a man-made flood-control structure, generally an earthen embankment or concrete floodwall, that is designed to contain or divert the flow of water along a river to reduce the risk of flooding in the area protected by the levee (U.S. Army Corps of Engineers, 2014). Other man-made features, such as roadways, may also function, intentionally or unintentionally, as levees. The U.S. Army Corps of Engineers (USACE) maintains the National Levee Database (NLD) of known levee locations, primarily those within the USACE Levee Program (U.S. Army Corps of Engineers, 2014). Many undocumented and commonly unmaintained levees exist in the landscape, which complicates flood forecasting, risk management, and emergency response. For the purpose of this report, an undocumented levee refers to man-made features intended to contain or divert the flow of floodwaters that are not included in the NLD. Undocumented levees may be maintained locally to unknown standards.

The cities of Delano, Minnesota, located on the South Fork Crow River, and Springfield, Minnesota, located on the Cottonwood River, are communities in Minnesota that do not have levees documented in the NLD (fig. 1). Both of the communities constructed temporary levees during flooding in 1969 and have since modified or raised the levees to continue to reduce flood risk for residents and infrastructure (Bolton and Menk, Inc., 2011; Robert Van Lith, city of Delano, Minn., oral commun., 2013). The two communities were selected for a pilot study completed by the U.S. Geological Survey (USGS) in cooperation with the USACE to assess two methods to identify undocumented levees using remotely sensed, highresolution topographic data.

The availability of high-resolution topography derived from light detection and ranging (lidar) data provides a dataset from which undocumented levees can be identified. Lidar is a remote sensing technology using laser light to measure the elevation of features of the Earth's surface (Minnesota Geospatial Information Office, 2014). Two methods were developed to identify undocumented levees from available gridded bare-earth digital elevation models (DEMs) derived from lidar data (Minnesota Geospatial Information Office, 2012). The first method involves the visual inspection of shaded relief layers (hillshades) computed from the DEMs (Esri, 2014) and 

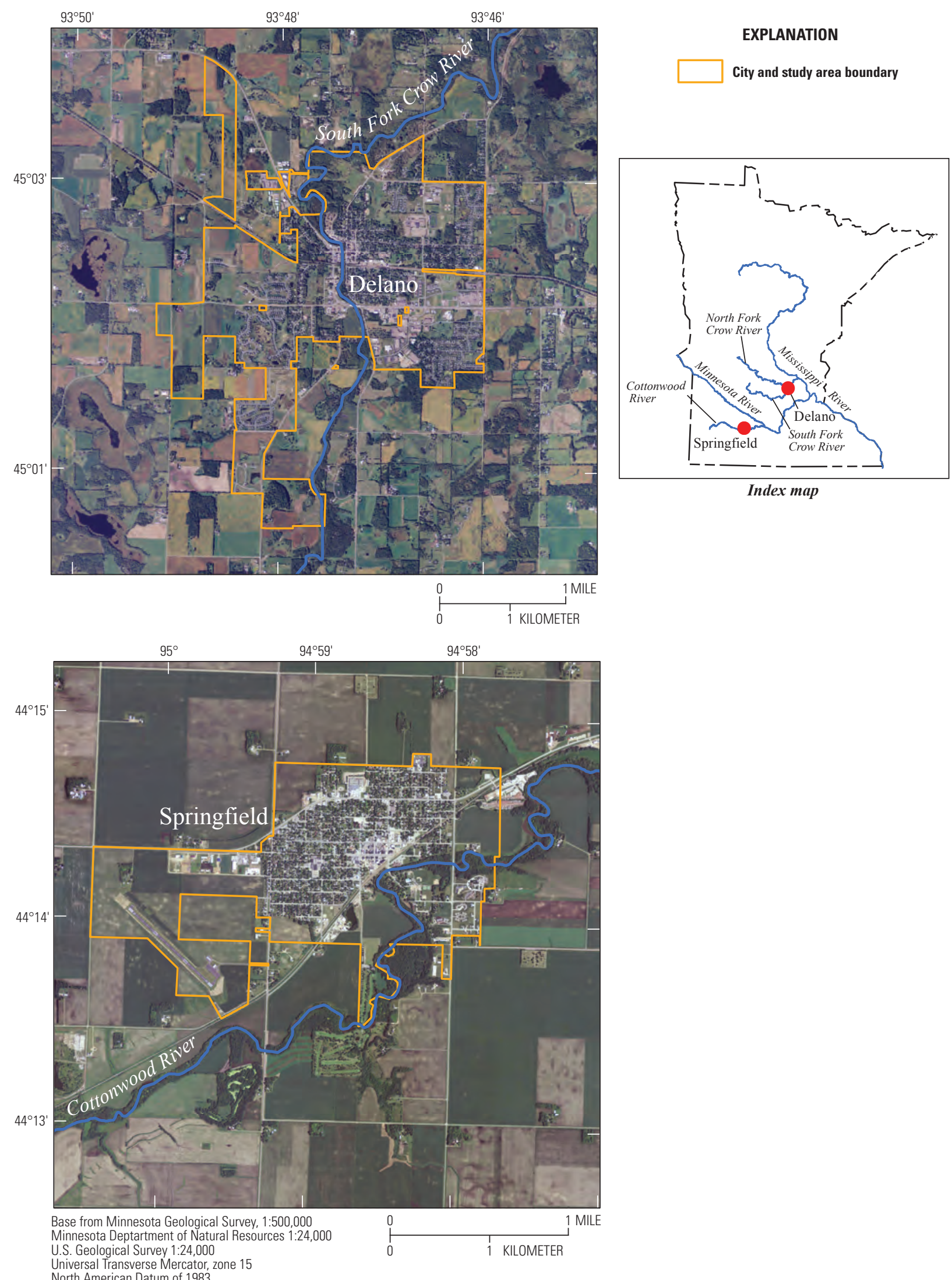

Figure 1. Location of study areas for the cities of Delano on the South Fork Crow River and Springfield on the Cottonwood River, Minnesota. 
manual delineation of potential levees. The second method is a semi-automated approach that involves applying a wavelet transform to the DEM, by which topographic signatures of potential levees are highlighted. A wavelet is a localized waveform (a curve) that is used in a wavelet transform (mathematical operation of comparing the wavelet to the landscape) to determine the dominant spatial scales of local landscape features (Addison, 2002). The wavelet-transform method highlights any land feature that has an abrupt vertical change in elevation, which includes levees as well as other features in the landscape. Verification of the methods was done by checking the identified features with local knowledge or site visits to confirm if the features were levees. By documenting the methods and selected characteristics of the potential levees examined, future efforts to identify undocumented levees in other and larger areas can be streamlined.

\section{Purpose and Scope}

The purpose of this report is to describe a pilot study to assess two methods for identifying undocumented levees using remotely sensed, high-resolution topographic data. The general approach was to use the locations of known undocumented levees to develop search criteria and to test methods for identifying potential levees near rivers using lidar-derived DEMs. The scope of this study is limited to the communities of Delano and Springfield, Minn., where undocumented levees were constructed during historical flood events.

The methods tested to identify undocumented levees were the hillshade and wavelet-transform methods. For the hillshade method, the USACE examined hillshades computed from the DEM to visually identify potential levees and then made a detailed site visit to assess the validity of the potential features. For the wavelet-transform method, the USGS applied a wavelet transform to the DEM to identify potential levees. Reporting the USGS method might lead to more automated identification of levees. Characteristics of the potential levees are presented to demonstrate the typical size of levees analyzed in this pilot study.

\section{Study Area Descriptions}

The communities of Delano and Springfield, Minn., were chosen as study areas for this pilot study because they are locations with undocumented levees. City officials of Delano, located on the South Fork Crow River, and Springfield, located on the Cottonwood River (fig. 1), constructed or subsequently raised levees during past flood threats to reduce flood risk for residents and infrastructure. The study areas do not have any levees listed in the NLD; therefore, any levees that exist in Delano or Springfield are undocumented.

\section{South Fork Crow River at Delano, Minnesota}

The South Fork Crow River is located in south-central Minnesota. The South Fork Crow River flows generally eastward to its confluence with the North Fork Crow River to become the Crow River, which flows into the Mississippi River (fig. 1). The Minnesota Department of Natural Resources (MNDNR) has streamflow records beginning in August 1998 for the South Fork Crow River at Delano, Bridge Avenue streamgage (MNDNR site identifier 19001001) (http:// www.dnr.state.mn.us/waters/csg/site_report.html?mode=get site_report\&site=19001001). The National Weather Service (NWS) Advanced Hydrologic Prediction Service (AHPS) issues flood forecasts for the South Fork Crow River at Delano, Bridge Avenue streamgage location during high flow and maintains a historical record of peak-flood stages dating back to 1965 before the installation of the MNDNR streamgage.

The 10 highest historical crests from flood waves are listed in table 1 , and all crests exceeded the major flood stage defined as 18.5 feet (National Weather Service, Advanced Hydrologic Prediction Service, 2014a).

The peak flood of record was in spring of 1965. Levees along the South Fork Crow River, which were initially built for temporary flood protection in preparation of the spring 1969 flood, have been maintained and enhanced sporadically through time according to annual flood forecasts (Robert Van Lith, city of Delano, Minn., oral commun., 2013).

Table 1. Ten highest historical flood wave crests through 2014 for the South Fork Crow River at Delano, Bridge Avenue streamgage, Minnesota (National Weather Service, Advanced Hydrologic Prediction Service, 2014a).

[Stage is referenced to the local gage datum]

\begin{tabular}{ccc}
\hline Rank & Stage, in feet & $\begin{array}{c}\text { Date } \\
\text { (month/day/year) }\end{array}$ \\
\hline 1 & 23.25 & $04 / 14 / 1965$ \\
2 & 21.02 & $06 / 24 / 2014$ \\
3 & 20.45 & $04 / 12 / 1969$ \\
4 & 20.30 & $03 / 21 / 2010$ \\
5 & 20.00 & $03 / 28 / 2011$ \\
6 & 19.95 & $04 / 15 / 2001$ \\
7 & 19.25 & $04 / 08 / 1997$ \\
8 & 18.85 & $04 / 30 / 2001$ \\
9 & 18.75 & $09 / 16 / 1991$ \\
10 & 18.75 & $06 / 25 / 1993$ \\
\hline
\end{tabular}




\section{Cottonwood River at Springfield, Minnesota}

The Cottonwood River is located in southwestern Minnesota and generally flows eastward to its confluence with the Minnesota River (fig. 1). The MNDNR has streamflow records beginning in October 1999 for the Cottonwood River near Springfield, CR2 streamgage (MNDNR site identifier 29015001) (http://www.dnr.state.mn.us/waters/csg/site_report. html?mode=get_site_report\&site=29015001). The NWS AHPS issues flood forecasts for the Cottonwood River near Springfield, CR2 streamgage location during high flow. The 10 highest historical crests from flood waves are listed in table 2 (National Weather Service, Advanced Hydrologic Prediction Service, 2014b).

Springfield, Minn., is situated along the banks of the Cottonwood River (fig. 1), and within the city limits, the river flows generally northeastward. Flood protection for the city includes an earthen levee along the north side of the Cottonwood River that was first constructed in spring of 1969 in preparation for a flood threat (Bolton and Menk, Inc., 2011). The levee was constructed in an emergency situation to protect against rising floodwaters, using any materials that could be found (Bolton and Menk, Inc., 2011). Although constructed as a temporary levee, this feature has remained in place. In the spring of 2011, additional material was used to raise the earthen levee in response to a large forecasted flood (Bolton and Menk, Inc., 2011). Because of the lack of quality control when the levee was first constructed, and seepage observed in fall 2010, the city of Springfield has reconstructed and enhanced the levee (Bolton and Menk, Inc., 2011).

Table 2. Ten highest historical flood wave crests through 2014 for the Cottonwood River near Springfield, CR2 streamgage, Minnesota (National Weather Service, Advanced Hydrologic Prediction Service, 2014b).

[Stage is referenced to the local gage datum]

\begin{tabular}{ccc}
\hline Rank & Stage, in feet & $\begin{array}{c}\text { Date } \\
\text { (month/day/year) }\end{array}$ \\
\hline 1 & 32.89 & $09 / 24 / 2010$ \\
2 & 32.70 & $04 / 24 / 2001$ \\
3 & 31.55 & $04 / 08 / 1969$ \\
4 & 31.40 & $06 / 18 / 1993$ \\
5 & 30.06 & $03 / 23 / 2011$ \\
6 & 29.12 & $06 / 25 / 1984$ \\
7 & 28.79 & $05 / 08 / 1983$ \\
8 & 28.77 & $03 / 29 / 1997$ \\
9 & 26.82 & $09 / 22 / 1986$ \\
10 & 26.62 & $03 / 31 / 1979$ \\
\hline
\end{tabular}

\section{Two Methods for Identifying Undocumented Levees Using Remotely Sensed Data}

Two methods were used to identify undocumented levees from remotely sensed, high-resolution topographic raster (gridded) data. For the first method, the USACE examined hillshades computed from a DEM derived from lidar for Delano, Minn., to visually identify potential levees. The USACE then made a detailed site visit to assess the validity of the potential levees. For the second method, the USGS applied a wavelet transform to the topography to identify potential levees in Delano and Springfield, Minn. Both methods were verified by comparing the results to known undocumented levee locations, and results from the methods were compared for the city of Delano.

The lidar data used in this study were available from the Minnesota Geospatial Information Office (http://www. mngeo.state.mn.us/chouse/elevation/LiDAR.html). The data were downloaded as bare-earth DEMs that are free of vegetation, buildings, and other man-made structures and have an elevation point at each 1-meter $(\mathrm{m})$ grid spacing (Minnesota Geospatial Information Office, 2012). The data for Delano were part of the spring 2008 Wright County lidar flight, and the data for Springfield were part of the spring and fall 2010 Brown County lidar flight.

Four characteristics of the identified potential levees were described as part of the analysis. The characteristics are the average top width of the levee, average width of the base of the levee (levee width), average landward height, and average streamward height (shown schematically in figure 2). The characteristics were measured from elevation cross sections that were sampled at 3-10 locations of approximately equal spacing along each potential levee and averaged. The sampled locations were determined based on professional judgment to estimate how the levee sizes compare to each other, to the DEM cell size, and to the wavelet scale. The locations were not intended as a rigorous quantification of the characteristics. The levee top width is the width of the approximately horizontal highest part of the levee. The levee width is the width of the levee where it meets the land surface. The streamward height is the difference in elevation from the top of the levee to the approximate water surface represented in the DEM. The landward height is the difference in elevation from the top of the levee to the land surface behind the levee. The characteristics were measured to demonstrate the typical size of potential levees identified by the methods used in this pilot study. 


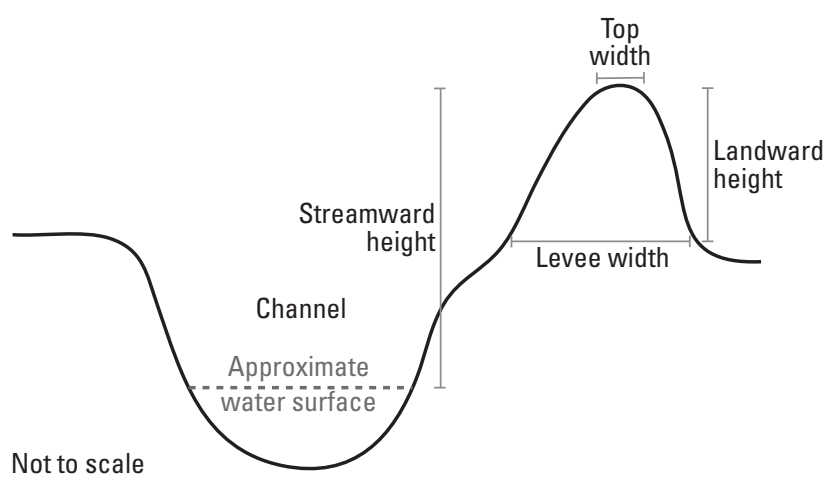

Figure 2. Schematic showing measured dimensions of levees.

\section{Hillshade Method and Site Visit Verification}

The USACE tested a visual analysis (manual) approach to identifying potential levees from hillshade data and then verified the identified features through site visits and discussions with local managers. The method was tested for the South Fork Crow River at Delano, Bridge Avenue, Minn.

Hillshade layers were computed from the DEM using the default settings in the Hillshade tool in the Spatial Analyst toolbox of ArcMap software (Esri, Redlands, California). A hillshade is a shaded relief image or raster computed from a DEM using an illumination source at a specific elevation and direction from the DEM (Esri, 2014). The Hillshade tool can be used to highlight areas that face the illumination source and shade areas that face away from the source. Topographic relief, including levees, is more prominently visible in a hillshade layer computed from the DEM than in displays of the DEM itself. The hillshades computed from the DEM for Delano were visually analyzed to identify potential levees. Raised linear features near the river that appeared to be levees were delineated in a geospatial line file of potential levees. The delineation was validated by another individual of the USACE.

Eight features were initially identified as potential levees (red-line features labelled d-1, d-2, d-3a, d-4, d-5a, d-7, d-8, and d-9 [fig. 3]) from the hillshade layers. The eight potential levees were assessed in the field on June 27, 2013, to document the condition and characteristics of the features and determine if they were, in fact, levees. The locations of the levees also were confirmed by representatives of the city of Delano (Robert Van Lith, Fire Chief, city of Delano, Minn., oral commun., 2013; and Paul Swearengin, city of Delano, Minn., Public Works Department, oral commun., 2013).

Following the initial site visit in June 2013, five of the eight initially identified potential levees were confirmed as levees (table 3 ). Of the remaining three features initially identified as potential levees, feature d- 1 was a natural beach ridge only slightly higher than the floodplain and would not substantially affect the flow of floodwaters. Feature d-7 was a low embankment built to keep mining spoils out of the river and is not expected to function as a levee or to provide flood protection. Feature d-9 was an earthen embankment that was created to provide a visual barrier between a housing development and the sewage treatment plant and does not tie into higher ground. Therefore, feature d-9 would not function as a levee because water is able to freely flow around the feature.

After completion of the initial site visit, all collected data (geotagged photos, field notes, and geospatial data) were submitted to a review team comprised of USACE personnel. The review team determined that three additional potential levees (yellow-line features labeled d-3b, d-5b, and d-6 [fig. 3]) warranted further investigation. A second field visit to Delano on July 18,2013 , and discussions with a local official, confirmed that the three features were levees that also were constructed as part of the effort to contain the 1969 flood (table 3; Robert Van Lith, city of Delano, Minn., Public Works Department, oral commun., 2013).

By using the hillshade method and verification field visits, the team confirmed the location and extent of eight undocumented levees in Delano (table 3). The hillshade layer was analyzed in the office before the site visit. Therefore, the site visit was more efficient because the team could focus on the assessment and on the discussions with city personnel. The field visits determined that several of the actual levee features were not obvious from ground-level inspection without prior knowledge of the levee locations. For example, figure $4 \mathrm{~A}$ shows an easily identifiable, maintained levee (feature d-8) and figure $4 B$ shows a heavily vegetated, abandoned, and unmaintained levee (feature d-6) that was not identified until the review team analyzed the topography and photographs following the first field visit.

In some areas, the DEM did not completely match conditions on the ground in summer 2013. For example, a new bridge had been constructed over the river since the lidar data collection in spring of 2008. The bridge was not apparent in the DEM, but was apparent in newer aerial photography. Even with some differences between the 2008 lidar data collection and the 2013 ground conditions, the DEM was superior for the purposes of levee detection to other readily available sources of information, such as USGS topographic maps and aerial photography. The 1-m horizontal resolution of the DEM was adequate to identify most potential levees in the city of Delano.

\section{Wavelet-Transform Method}

The USGS developed a method to identify potential levees by applying a wavelet transform to the DEM of Springfield, Minn. A wavelet is a localized waveform (a curve) that is used in a wavelet transform (Addison, 2002). For the purposes of this study, the mathematical operation compared the wavelet to the landscape to determine the dominant spatial scales of local landscape features. As a data analysis tool, wavelets have been used in many disciplines such as engineering, fluid mechanics, geophysics, medicine, and finance 


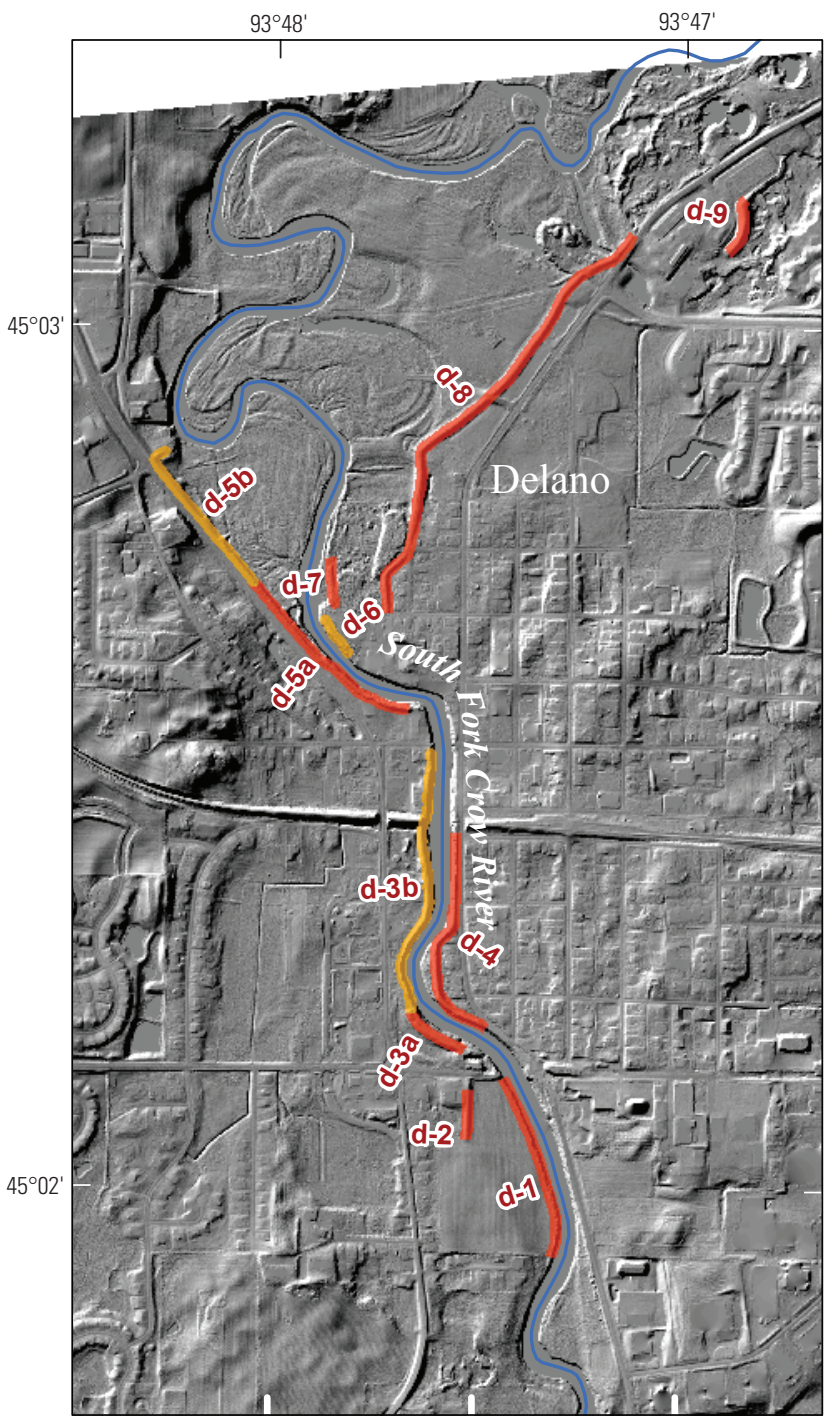

Base from the Minnesota Department of Natural Resources

Universal Transverse Mercator projection, zone 15

North American Datum of 1983

\section{EXPLANATION}

d-9 Initially identified potential levee before first field visit and identifier (table 3)

d-5b Potential levee identified after first field visit and identifier (table 3)

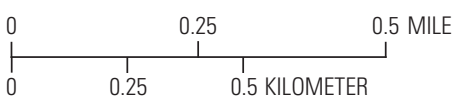

Figure 3. Potential levees identified using the hillshade method and field visits, Delano, Minnesota, 2013

Table 3. Summary of dimensions of assessed potential levees, Delano, Minnesota, 2013.

\begin{tabular}{lllcccc}
\hline $\begin{array}{c}\text { Feature } \\
\text { (fig. 3) }\end{array}$ & \multicolumn{1}{c}{ Final classification } & \multicolumn{1}{c}{ Condition } & $\begin{array}{c}\text { Average top } \\
\text { width, } \\
\text { in meters }\end{array}$ & $\begin{array}{c}\text { Average } \\
\text { levee width, } \\
\text { in meters }\end{array}$ & $\begin{array}{c}\text { Average } \\
\text { landward } \\
\text { height, } \\
\text { in meters }\end{array}$ & $\begin{array}{c}\text { Average } \\
\text { streamward } \\
\text { height, } \\
\text { in meters }\end{array}$ \\
\hline d-1 & Natural ridge & Moderate vegetation & 1.2 & 5.2 & 0.8 & 3.0 \\
d-2 & Levee & Light vegetation/moderate vegetation & 4.3 & 18.0 & 0.9 & 2.1 \\
d-3a & Levee & Walking path & 3.7 & 21.9 & 3.0 & 0.9 \\
d-3b & Levee & Heavy vegetation & 3.4 & 20.7 & 2.1 & 4.3 \\
d-4 & Levee & Heavy vegetation & 2.7 & 18.0 & 2.1 & 4.6 \\
d-5a & Levee & Heavy vegetation & 2.1 & 14.6 & 1.5 & 2.1 \\
d-5b & Levee & Heavy vegetation/light vegetation & 1.5 & 18.0 & 0.3 & 4.9 \\
d-6 & Levee (abandoned) & Heavy vegetation & 2.4 & 12.2 & 0.6 & 1.8 \\
d-7 & Pollution control embankment & Heavy vegetation & 3.3 & 12.3 & 0.8 & 3.0 \\
d-8 & Levee & Heavy vegetation/no vegetation & 4.6 & 25.3 & 2.1 & 2.4 \\
d-9 & Visual barrier & Light vegetation & 3.7 & 30.8 & 5.8 & 3.9 \\
\hline
\end{tabular}



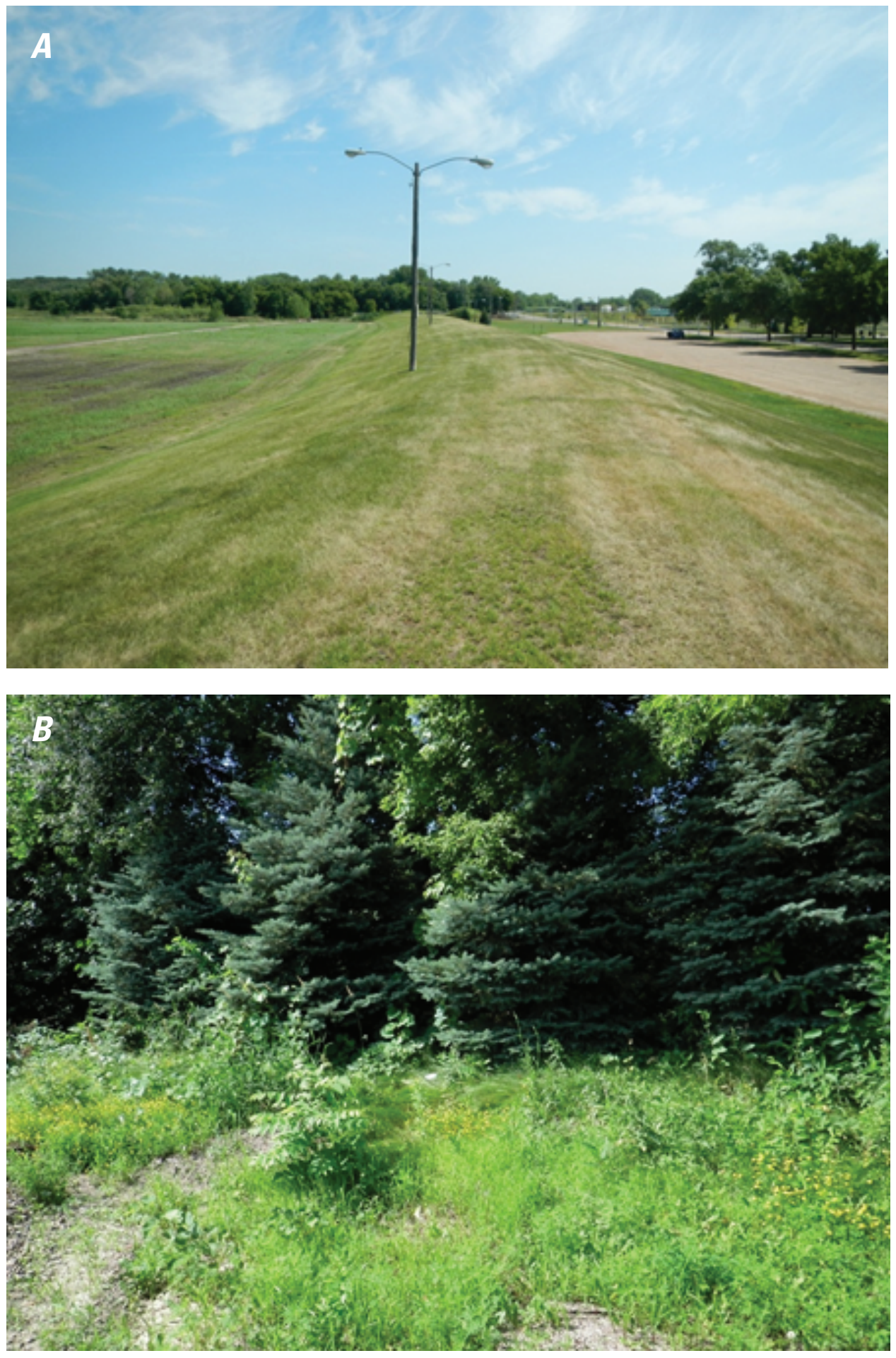

Figure 4. Levees assessed in the field by the U.S. Army Corps of Engineers, July 18, 2013, Delano, Minnesota (locations are shown in figure 3: $A$, is feature $d-8$ and $B$, is feature $d-6$ ). 
(Addison, 2002). In geophysics, wavelets have been used to study several processes including precipitation, hydrologic fluxes, turbulence, tree canopy cover, landscape topography, seafloor bathymetry, and ocean waves (Kumar and FoufoulaGeorgiou, 1994). Specifically related to topographic analysis, Lashermes and others (2007) used wavelets to identify river channels from high-resolution topographic data. As wavelets are well suited to identify localized abrupt changes in signal or image data (edge detection), wavelets were used in this study to identify potential levees in the landscape as represented by a DEM. A brief introduction to wavelets and the wavelet transform in one dimension, $x$, follows. Additional information on wavelets, the wavelet transform, and their application is presented by Addison (2002).

This study used the Mexican hat wavelet, $\psi(x)$ (fig. 5). The Mexican hat wavelet is the negative of the second derivative of the Gaussian distribution function for a mean of zero and standard deviation of one and is given for a single dimension by

$$
\psi(x)=\frac{2}{\sqrt{3} \pi^{1 / 4}}\left(1-x^{2}\right) e^{-x^{2} / 2}
$$

where

$x \quad$ is the support distance of the wavelet (unitless distance from the origin).

The wavelet described by equation 1 is known as a mother wavelet because it is the basic form of the wavelet from which the scaled and translated versions are obtained from that are used in the wavelet transform. This wavelet (eq. 1) can be stretched and squeezed (through a scale parameter, $a$, which is the distance between the center of the Mexican hat wavelet and its crossing of the x-axis [fig. 5]) and translated (through a location parameter, $b$ ) along the $\mathrm{x}$-axis. Specifically, scaled and translated versions of the mother wavelet, $\psi_{a, b}(x)$, are given by

$$
\psi_{a, b}(x)=\frac{1}{\sqrt{a}} \psi\left(\frac{x-b}{a}\right) .
$$

The mother wavelet (eq. 1) is recovered from equation 2 by setting $a=1$ and $b=0$.

The wavelet transform, $T(a, b)$, of a series, $z(x)$, with scaled and translated versions of the mother Mexican hat wavelet (eq. 2) is defined as

$$
T(a, b)=\int_{-\infty}^{\infty} z(x) \psi_{a, b}(x) d x .
$$

In this study, the wavelet transform is a measure of the local agreement in shape between the scaled wavelet and the elevation profile series. Equations 1-3 describe the Mexican hat wavelet and the wavelet transform in one dimension, but the ideas can be extended to two-dimensional elevation data for considering the wavelet transform of a three-dimensional surface like a DEM. In the two-dimensional case, the Mexican hat wavelet is rotated around its central axis (where $x=b$ ) and its graph looks like a bell, with $x$ representing the distance

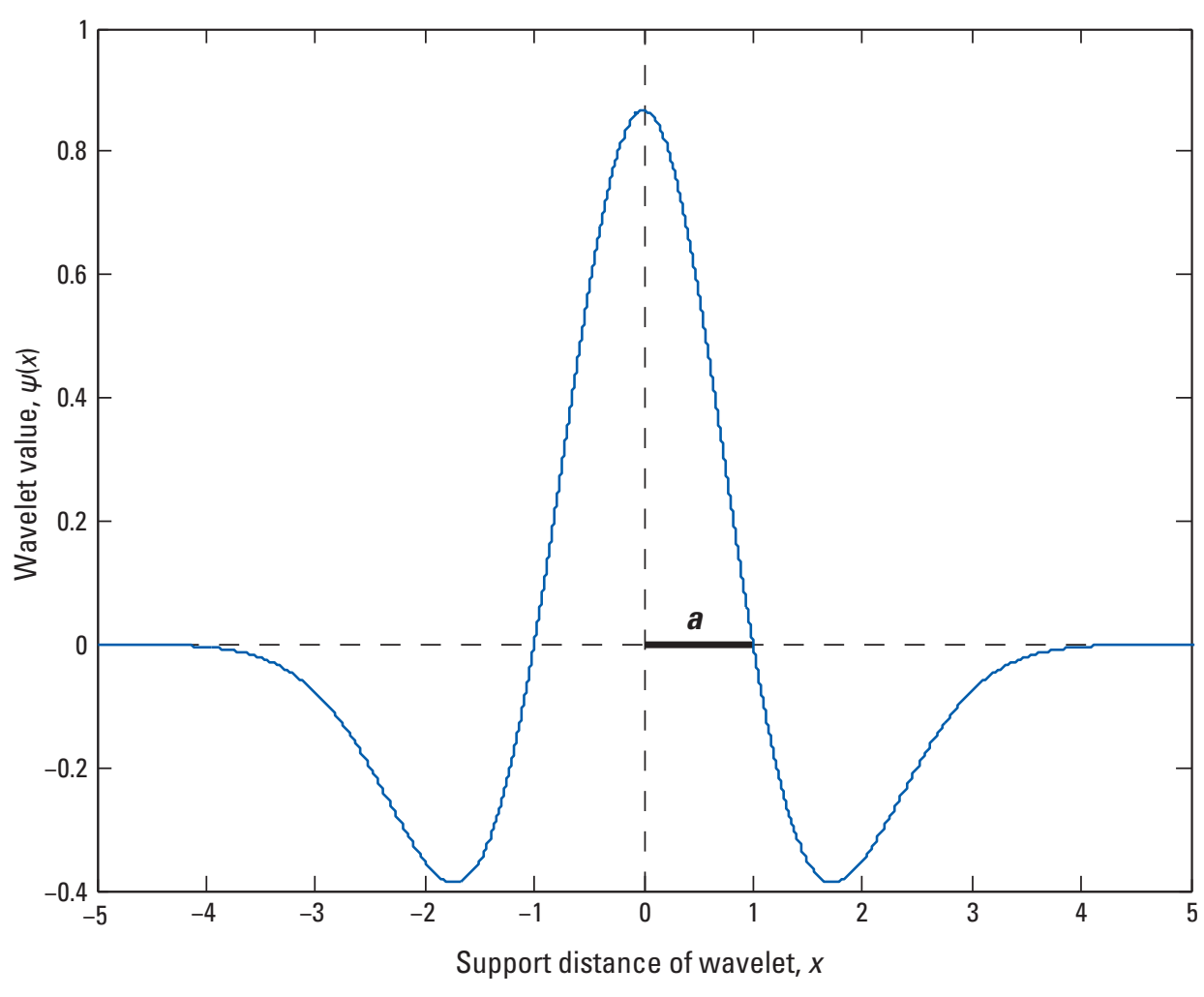

Figure 5. Mexican hat wavelet as a function of distance $(x)$, scale parameter $(a)$, and location parameter (b) ( $a=1$ and $b=0$ in the case shown). 
from the local origin in terms of easting and northing. Simplistically, a two-dimensional wavelet transform moves a scaled version of the bell around on the landscape, and the wavelet transform returns a coefficient describing the agreement in shape between the bell and the elevations of local landscape features, scaled by the height of the landscape feature. If the wavelet, at a specific scale and location, matches the shape of the landscape well, then a large wavelet-transform coefficient is obtained. For example, a round hill matching the scale of the wavelet would result in a large positive coefficient. However, if the wavelet and the shape of the landscape are not similar, for example uneven level or sloped ground, then a value near zero for the wavelet-transform coefficient is obtained. Thus, landscape features that look like the Mexican hat wavelet can be located in space by looking for large values of the wavelet-transform coefficient. Because the profile of levees approximates the shape of the Mexican hat wavelet well, the wavelet and the wavelet transform are ideally suited to identifying levees in the landscape and result in large coefficients along the length of the levee.

Potential levees were identified in Springfield by applying the two-dimensional Mexican hat wavelet transform to the DEM. The DEM data were formatted as an American Standard Code for Information Interchange (ASCII) file and read into MATLAB $^{\circledR}$ version 2013b (The MathWorks ${ }^{\circledR}$ Inc., Natick, Massachusetts, http://www.mathworks.com/) for processing. The MATLAB ${ }^{\circledR}$ function cwtft2, available in the Wavelet Toolbox, was used to compute the two-dimensional continuous wavelet transform of the elevation data at a particular scale.

The two-dimensional wavelet transform was done at scales of 3, 5, 10, and 15 (parameter a). For the DEM resolution of $1 \mathrm{~m}$, the scales gave the most weight for identifying potential levees that have widths of about $6,10,20$, and $30 \mathrm{~m}$, respectively. Levees with widths different than $6,10,20$, and $30 \mathrm{~m}$ can still be identified in the results from the wavelet transform at the scales of $3,5,10$, and 15 , but the levees may not be the most prominent features identified.

For any scale, the result of the two-dimensional continuous wavelet transform is a grid of wavelet-transform coefficients (dimensionless) that covers the extent of the DEM. Near the edges of the DEM, the wavelet-transform coefficients contain edge effects where the analyzed wavelet shape extends beyond the extent of the data. Wavelet-transform coefficients exhibiting edge effects are coefficients within $5 \times a$ (for the 1-m DEM and Mexican hat wavelet) of the data boundary, and the coefficients in this part of the analyzed domain were set to zero.

The convention used in the MATLAB ${ }^{\circledR}$ function for the two-dimensional continuous wavelet transform computed the Mexican hat wavelet as the two-dimensional version of the second derivative of the Gaussian function (not the negative of the Gaussian function as previously described for the one-dimensional case). Therefore, large negative coefficients returned by the two-dimensional wavelet transform corresponded to ridges of potential levees. To isolate the coefficients in the grid, all positive coefficients were set to zero, and then, for display purposes, all coefficients were multiplied by negative one to make positive values. Next, to further isolate potential levees, a threshold value was applied to the remaining nonzero coefficients and the coefficients below the applied threshold value were set to zero. Threshold values were set at the $0,50,75,90$, and 95 th percentiles of the coefficients.

Wavelet-transform coefficients at scales, a, of 3, 5, and 10 and with threshold values at the 50th and 90th percentiles for Springfield are shown in figure 6. Also shown on figure 6 are potential levees that include a levee reconstructed by the city (s-1), a roadway embankment (s-2), a quarry road (s-3), high steep river banks (s-4 [approximately $3-\mathrm{m}$ high]), and bluffs set back from the river (s-5 [approximately 8-m high]) (table 4). Features s-4 and s-5 were chosen as representative examples of sections of bank and bluffs among many such features that appear as highlighted areas in the wavelet-transform coefficients. As an edge-detection technique, the wavelet transform indiscriminately identifies land features with an abrupt change in elevation regardless of whether or not the land features are in fact levees. Currently (2014), some interpretation of the wavelet-transform coefficients is required to separate levees from other highlighted features such as steep banks and bluffs.

The features (s-1 to s-5) identified in Springfield were checked and confirmed by Scott Johnson, Emergency Manager and Utilities Superintendent for the city of Springfield. Without obtaining more information on specific features from field visits or from local managers, the effects of the features on flood flows may be misinterpreted from topographic analysis alone. For example, the quarry road (feature s-3) might function as a levee during a flood; however, a culvert is underneath the road that would hydraulically connect any floodwaters on each side of the feature. Therefore, even though feature s-3 might have some effect on flood flows, the feature is not expected to function as a levee (Scott Johnson, city of Springfield, Minn., oral commun., 2014).

\section{Comparison of Methods}

The two methods were compared for Delano, Minn., to determine how well each method was able to independently identify levees. Wavelet-transform coefficients at scales of 3,5 , and 10 and with threshold values at the 50th and 90th percentiles for Delano are shown in figure 7. Several potential levees were identified as linear features along the river. At high thresholds, only the most prominent features remain because other values of the wavelet-transform coefficients are filtered out. However, at even larger scales, the highlighted features change as some features appear or disappear depending on the characteristic size of the feature.

The major levees at Delano were identified by both methods (fig. 8). Certain levees were more difficult to identify from looking at the filtered display of wavelet-transform coefficients such as the southern extent of feature $\mathrm{d}-8$, which is narrower than the rest of the levee. The southern part of feature 

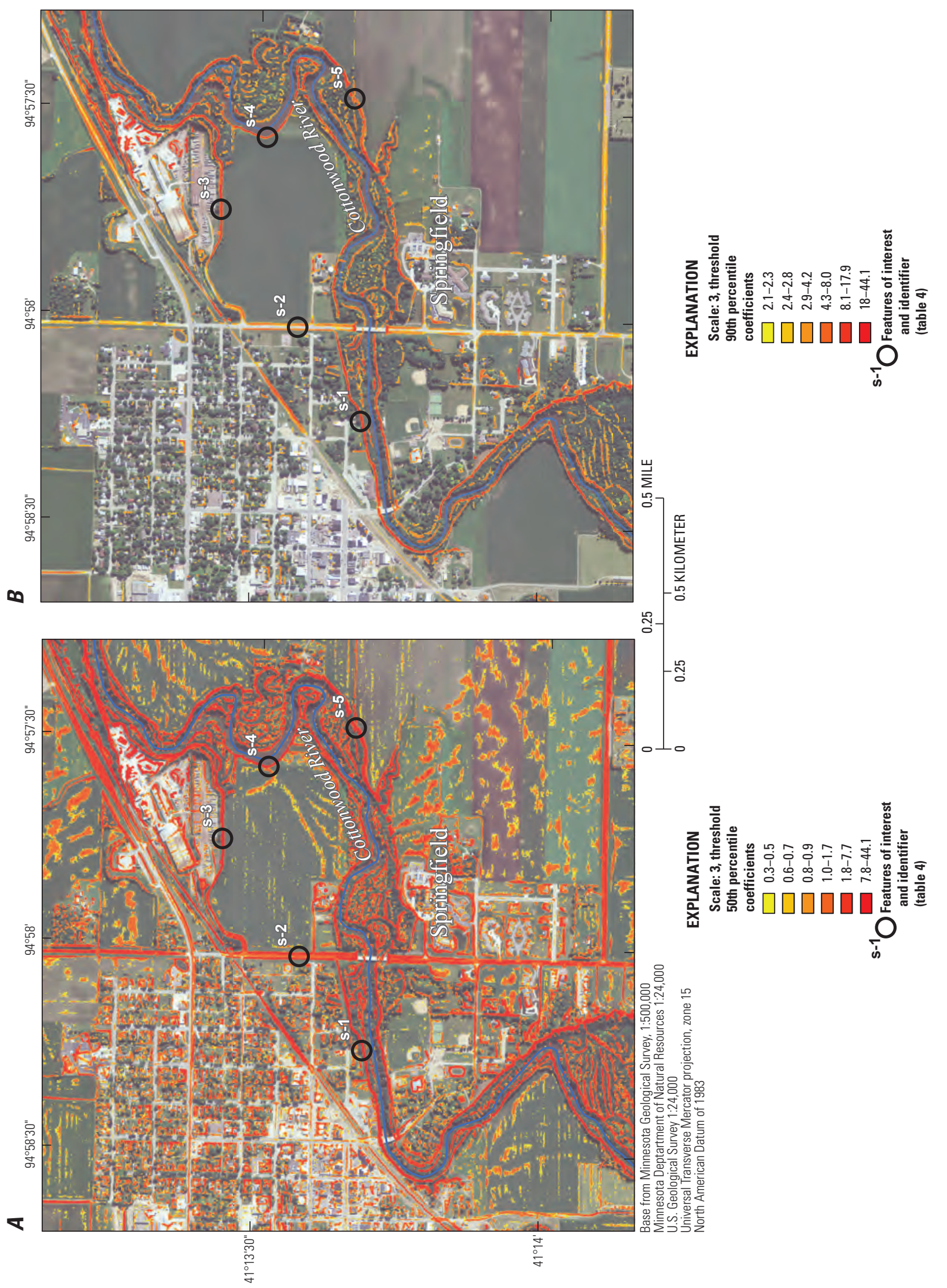

$\stackrel{\oplus}{\rightleftarrows}$

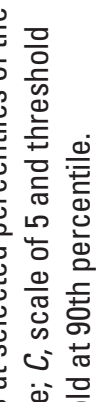

후응

응 흘

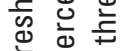

들 듣

흘 융

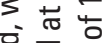

흥 흥 엏

든 너

产 음

ल

을 论

응 잉

๙

Ф્仓

至

든 덩 응

증 닝 듬

을 인

ত্ ई吉

先 䒕 荧

흠으 피

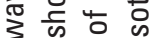

ఏ

is 焉

드욜

त

등 范产造

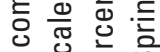

잉 के

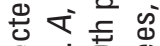

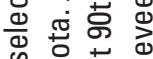

허ㅇㅝㅡ

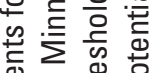

Ф

는 음 뭉

速 응

ن.

हो के

क ल

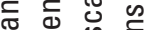

京造这

屯

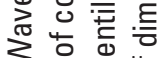

$>$ प

๑ 을 늘

늘 을 을 

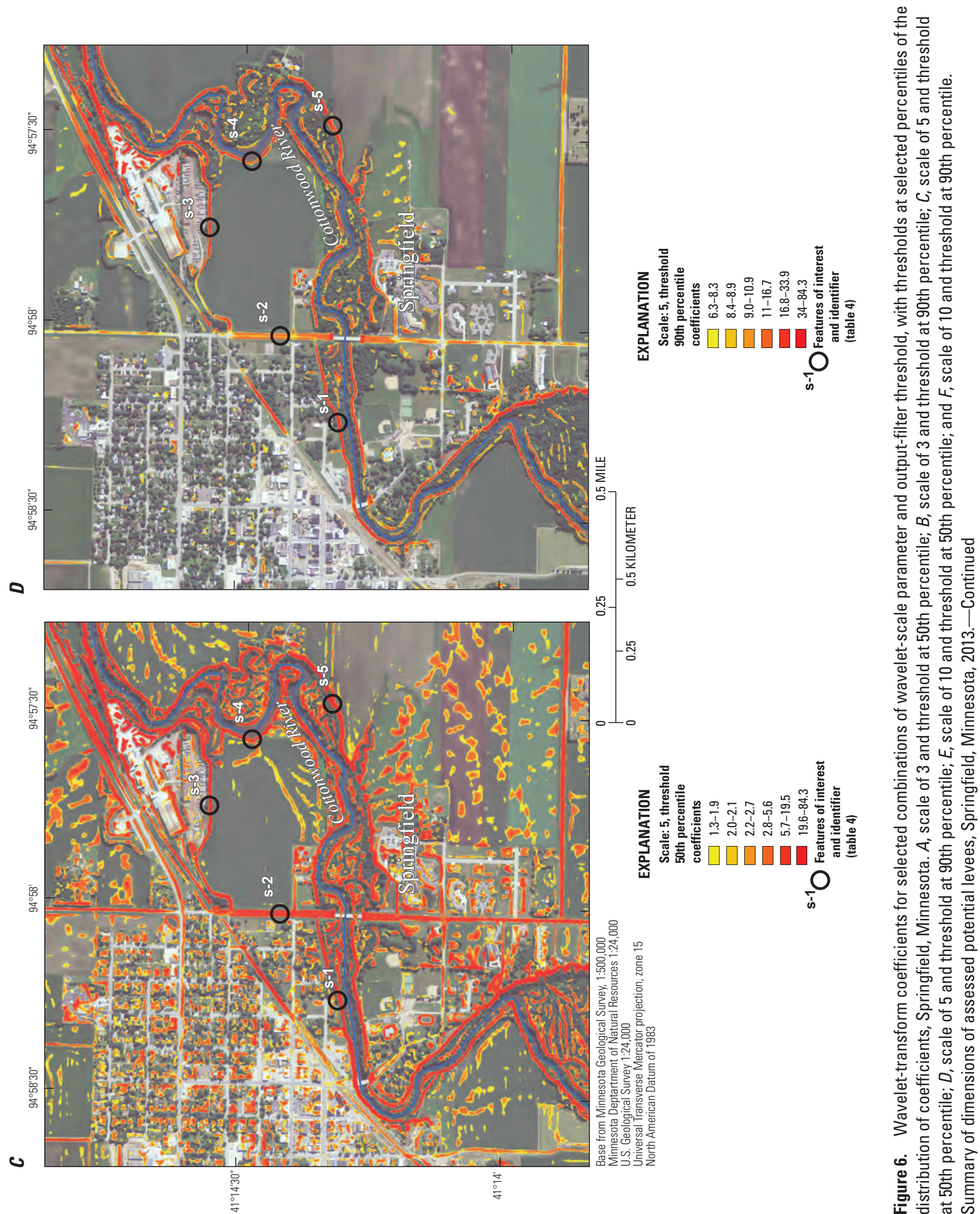


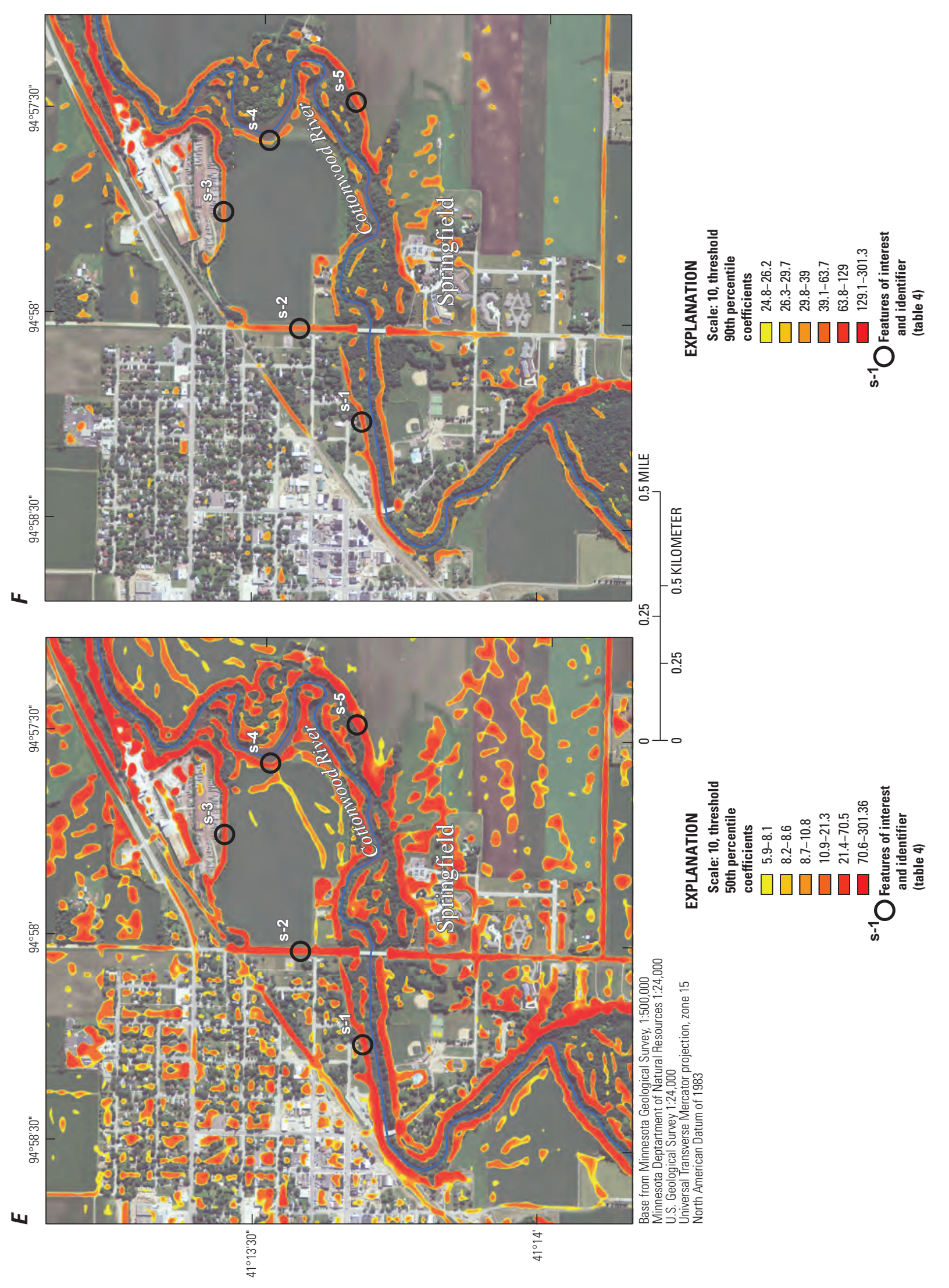

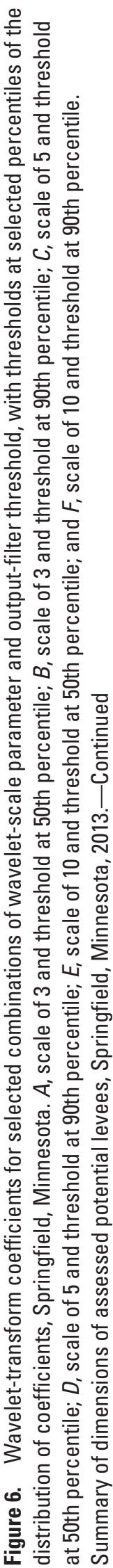


Table 4. Summary of dimensions of assessed potential levees, Springfield, Minnesota, 2013.

[--, not applicable]

\begin{tabular}{|c|c|c|c|c|c|c|}
\hline $\begin{array}{l}\text { Feature } \\
\text { (fig. 6) }\end{array}$ & Final classification & Condition & $\begin{array}{c}\text { Average } \\
\text { top width, } \\
\text { in meters }\end{array}$ & $\begin{array}{c}\text { Average } \\
\text { levee width, } \\
\text { in meters }\end{array}$ & $\begin{array}{l}\text { Average } \\
\text { landward } \\
\text { height, } \\
\text { in meters }\end{array}$ & $\begin{array}{c}\text { Average } \\
\text { streamward } \\
\text { height, } \\
\text { in meters }\end{array}$ \\
\hline $\mathrm{s}-2$ & $\begin{array}{l}\text { Roadway, likely functioning as } \\
\text { levee }\end{array}$ & Road & 13.8 & 40.0 & 2.6 & 13.2 \\
\hline $\mathrm{s}-4$ & Bank $^{2}$ & Light vegetation/moderate vegetation & -- & -- & -- & 3.2 \\
\hline s-5 & Bluff $^{2}$ & Heavy vegetation & -- & -- & -- & 8.0 \\
\hline
\end{tabular}

${ }^{1}$ These features are not adjacent to the river and the average streamward height in this case refers to the height of the feature above the adjacent land on the side nearest the river.

${ }^{2}$ These features do not have a levee-like shape, so the only applicable measurement is the height of the bank or bluff above the water.

d-8 was more apparent in results for the wavelet scale of 3 (figs. $7 B$ and $8 B$ ) and was harder to identify when wavelets of larger scales were used (fig. $7 F$ ), generally because of the small top width (approximately $2 \mathrm{~m}$ ). The wavelet-transform coefficients highlight a variety of breaks in slope that are not levees, requiring examination of the results to identify potential levees. However, some features that were not initially identified by the hillshade method were identified consistently by the wavelet-transform method.

\section{Assessment of the Methods Used to Identify Undocumented Levees}

The hillshade method, which was used for the Delano, Minn., area, used a combination of the basic spatial analysis procedures for a geographic information system (GIS), the knowledge of local officials, and thorough site visits. The method allowed for a robust, though relatively straightforward, way of examining the existence and positioning of undocumented levees that relied on manual examination of the data. Therefore, the approach was time and resource intensive as well as possibly inconsistent because of the reliance on individual professional judgment. The field visit provided a detailed review of the identified potential levees in the vicinity of the river.

The wavelet-transform method was used to apply a variety of wavelet transforms to the DEM to identify potential levees and, because it was semi-automated, was qualitatively less time and resource intensive than the hillshade method. Using different wavelet-scale parameters and applying different thresholds to filter the transform results helped to extract the most prominent features as a wide array of potential levees are identified using the wavelet-transform method. By visually comparing identified potential levees with aerial imagery and other available GIS datasets, computer-identified features that would not affect the flow of flood waters could be disregarded.

The hillshade and wavelet-transform methods were successful in identifying levees. However, the methods also identified other features that required interpretation or site visits to differentiate from levees such as constructed barriers, high banks, and bluffs. Additionally, testing the wavelettransform method in Delano allowed for direct comparison of the two methods. Each method identified actual levees that were missed when the other method was used; thus, when used in isolation, each method had limitations. If the methods had been used together, all of the features possibly would have been identified remotely before the second site visit. In summary, the two methods are complementary to each other. Using the hillshade method in conjunction with the wavelettransform method would provide more reliable results more efficiently by possibly eliminating the need for a second site visit or, at least, limiting the scope of the second visit.

\section{Potential Method for Future Applications}

The two methods assessed in this study are complementary for future applications, creating a potential three-step procedure for identifying potential levees from lidar-derived DEMs. The semi-automated wavelet-transform method can be used as a first step for a large area to rapidly highlight slopebreak features in the landscape that are potential levees. For the second step, a smaller area then can be more closely examined using the interpreted results of the wavelet-transform method along with the hillshades computed from the DEM. The interpretive second step, which may involve ancillary data as well, aids in the development of a map of potential levees. The third step is verifying the potential levees by field inspection and by talking to local officials. 

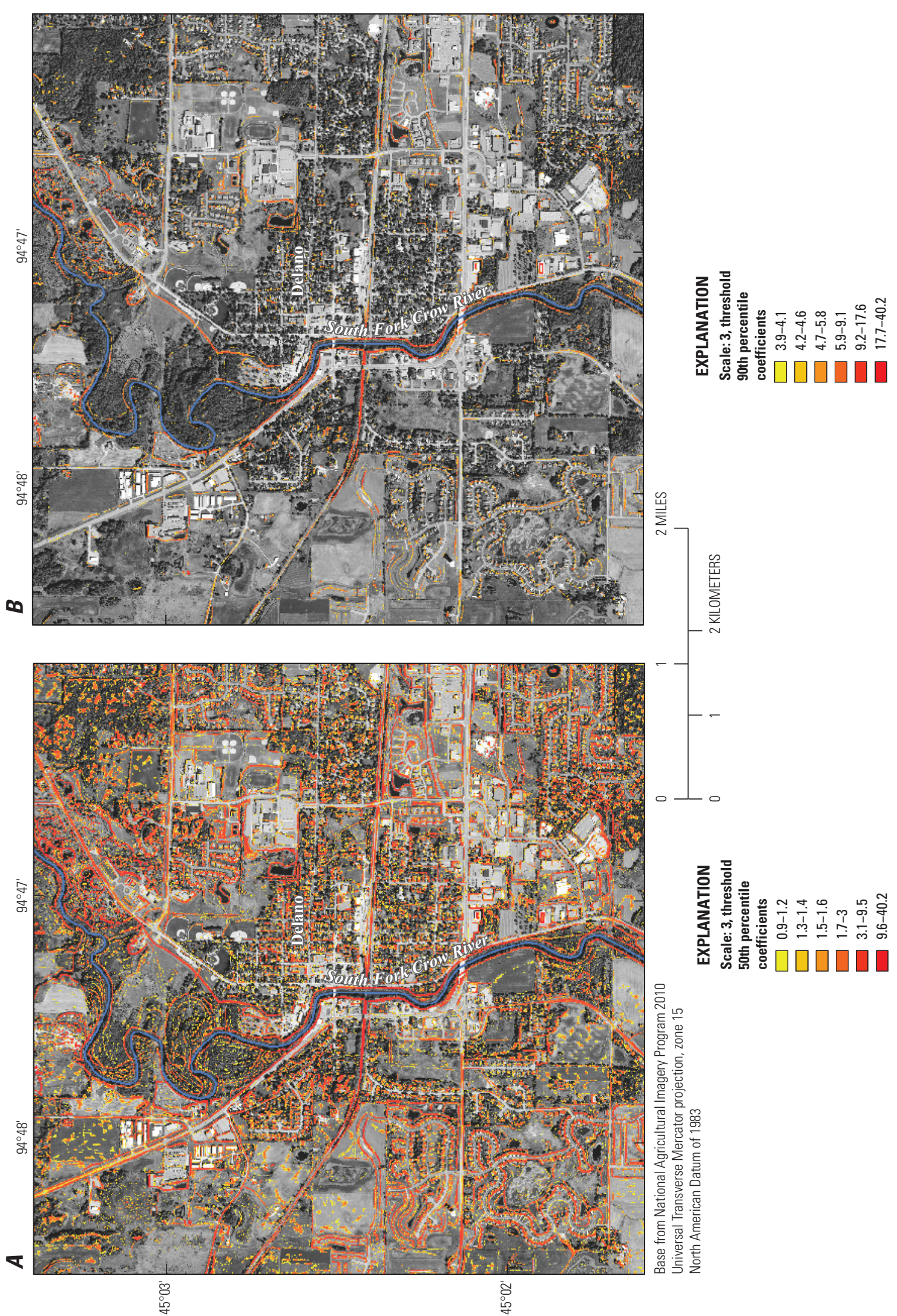

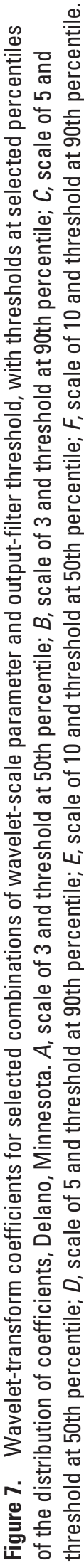




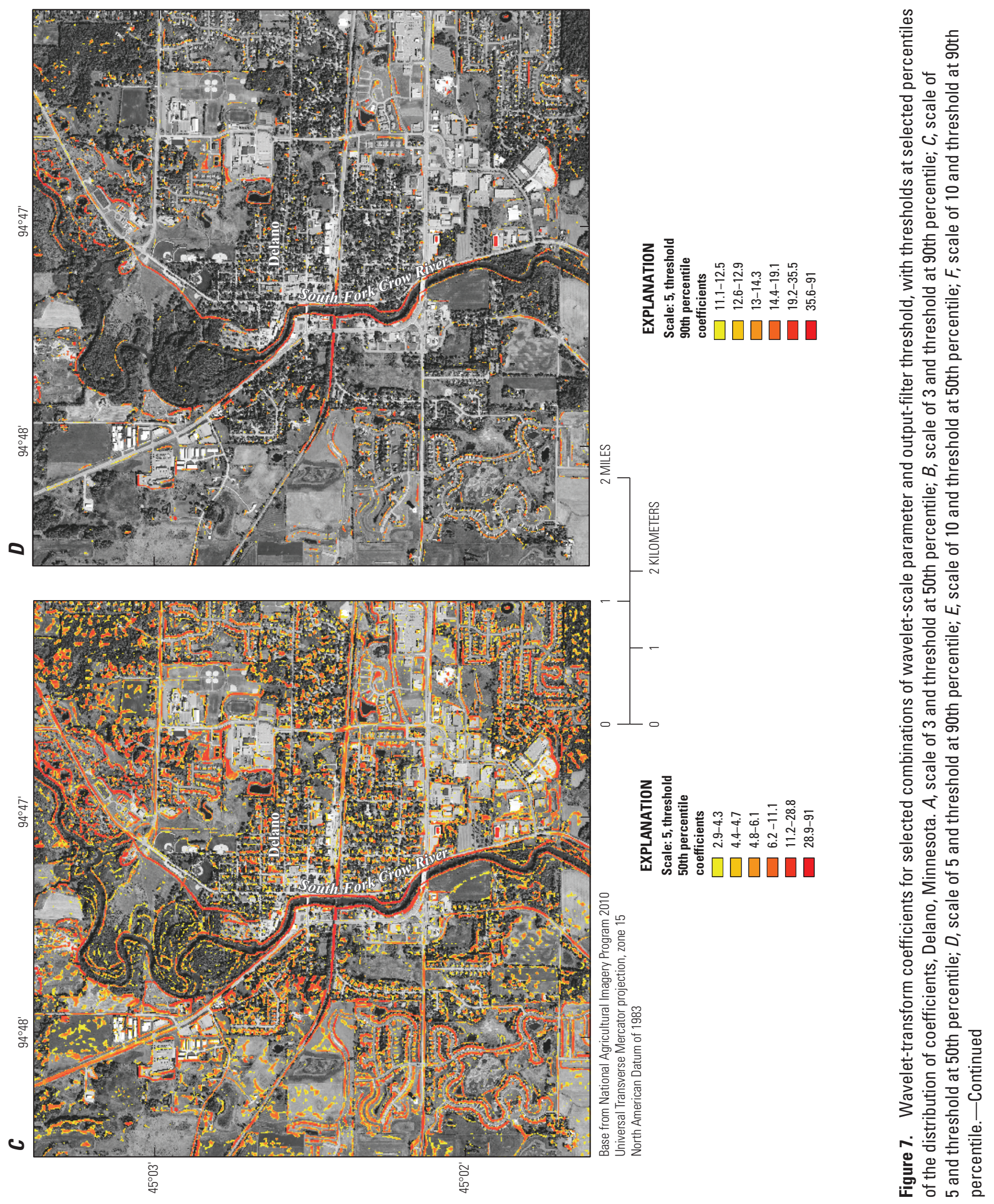



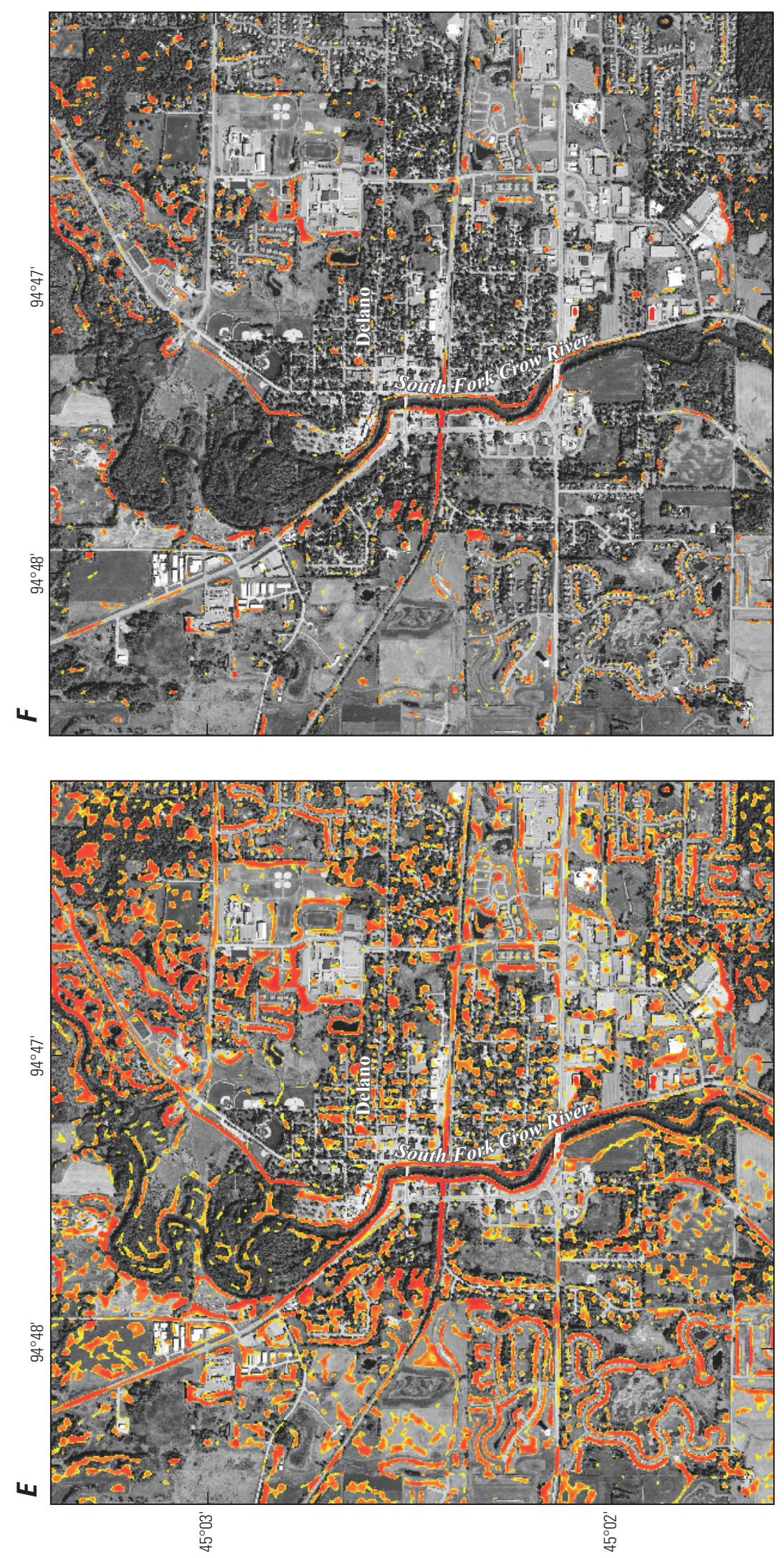
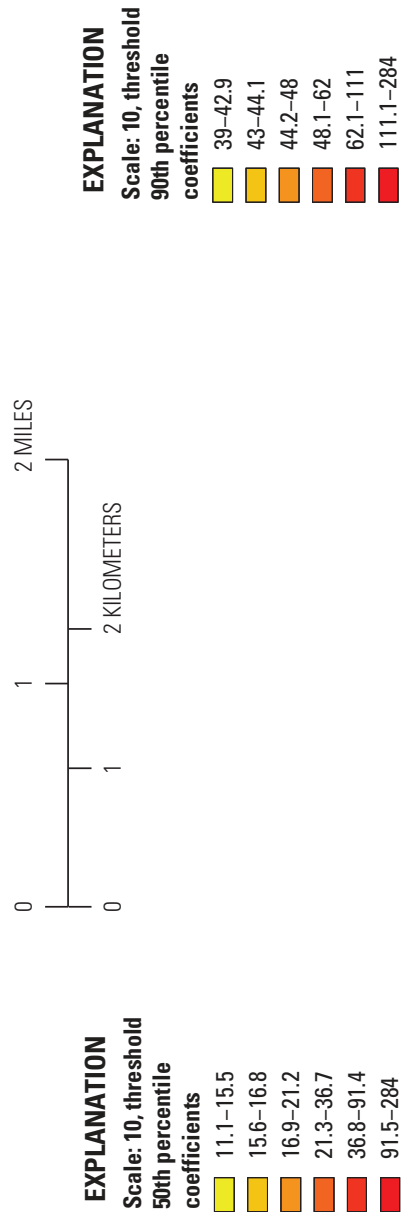

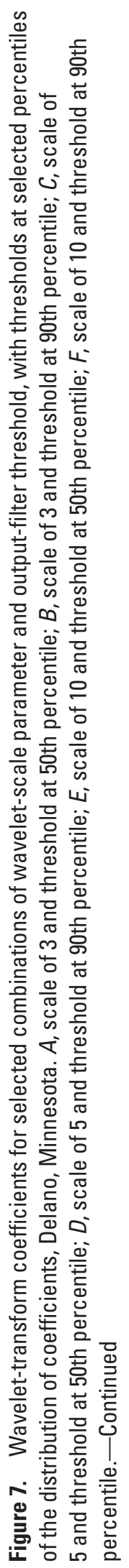




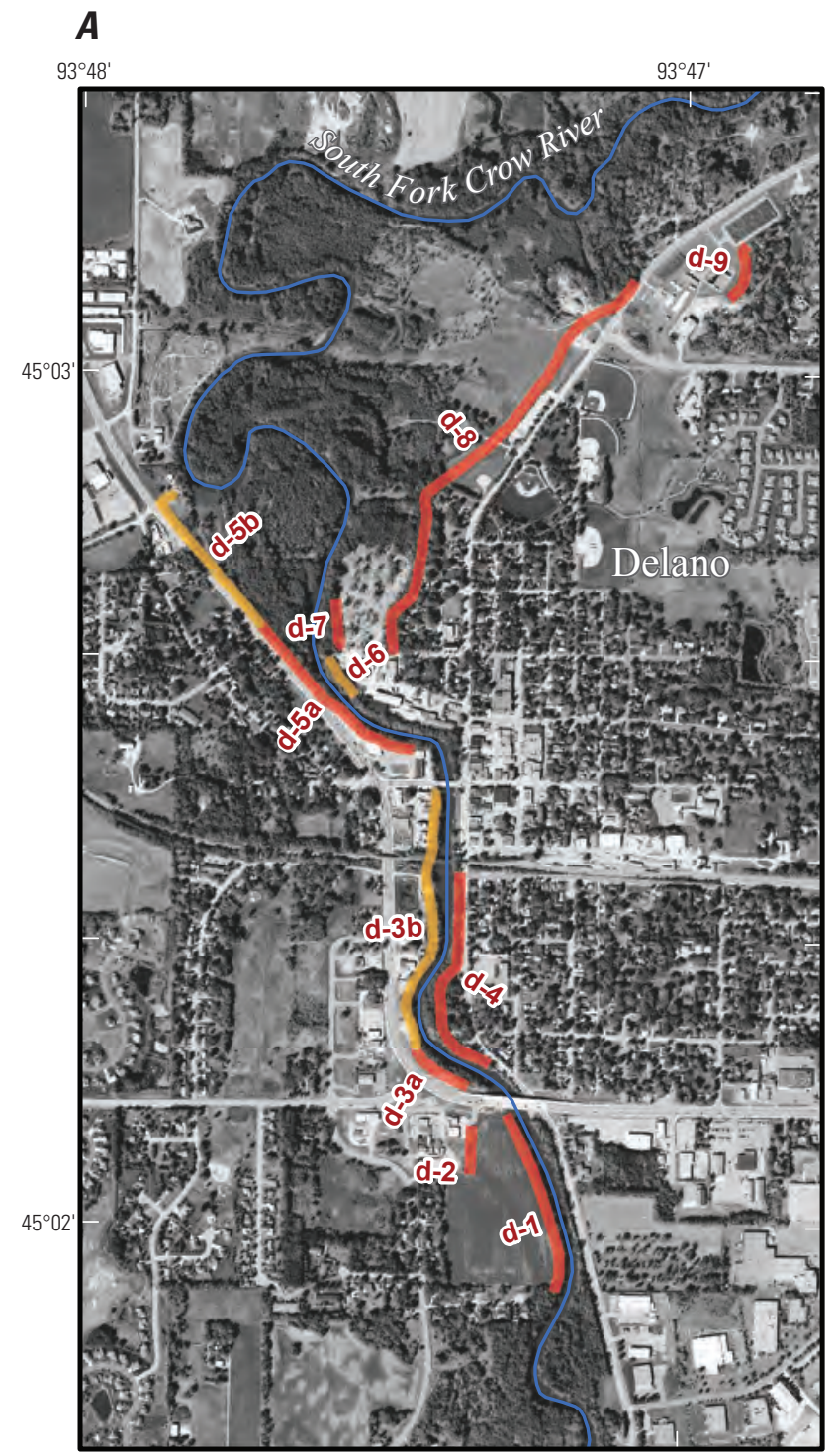

$\begin{array}{ll}\boldsymbol{B} & 93^{\circ} 47^{\prime} \\ 3^{\circ} 48^{\prime} & \end{array}$

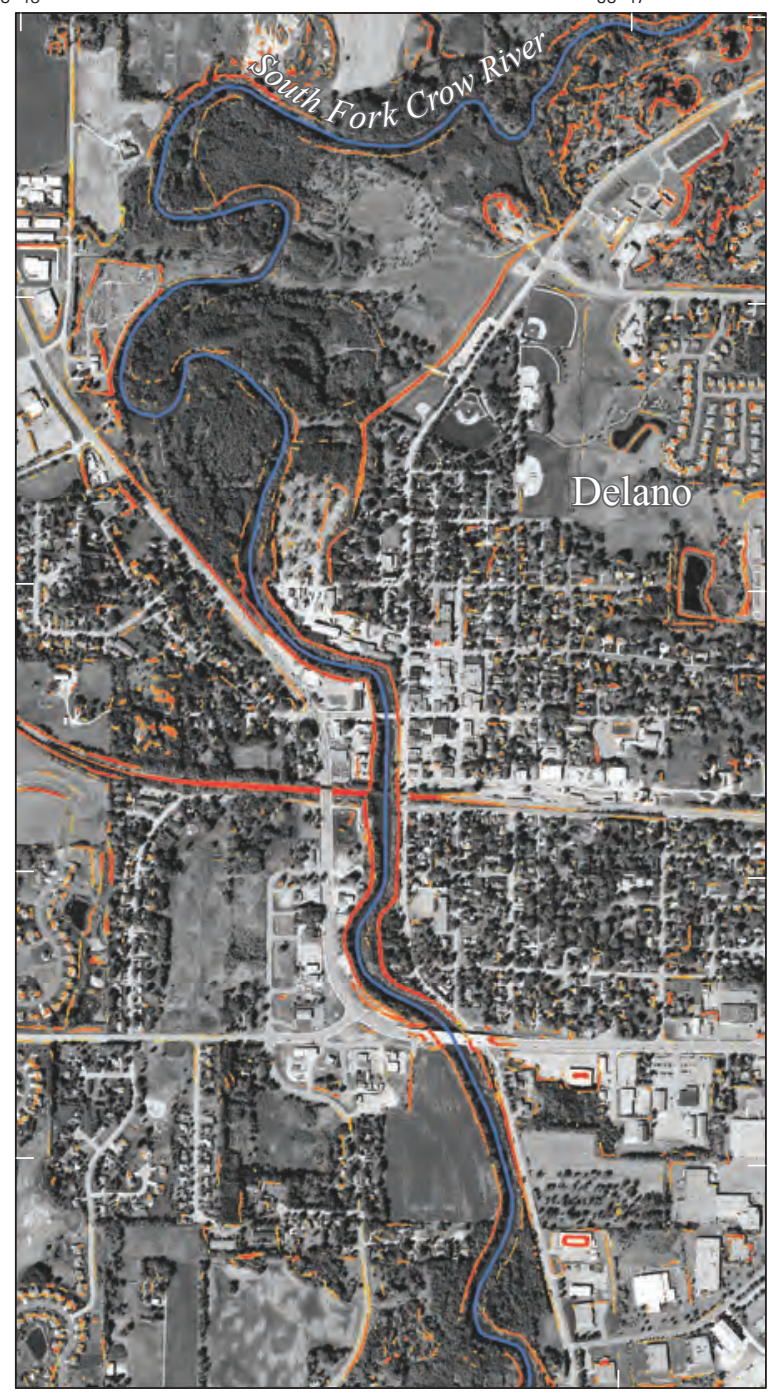

Base from National Agricultural Imagery Program 2010 North American Datum of 1983

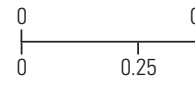
0.25 $0.5 \mathrm{MILE}$

EXPLANATION

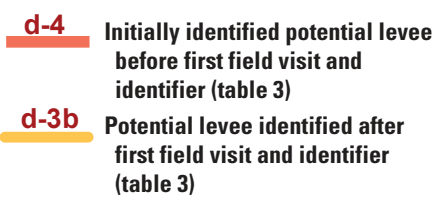

\section{EXPLANATION}

Scale: 3 , threshold 90th percentile

Wavelet transform coefficients

$$
\begin{aligned}
& \square \quad 3.9-4.1 \\
& \square \quad 4.2-4.6 \\
& \square \quad 4.7-5.8 \\
& \square \quad 5.9-9.1 \\
& \square \quad 9.2-17.6 \\
& \square \quad 17.7-40.2
\end{aligned}
$$

Figure 8. Comparison of potential levees identified by two methods, Delano, Minnesota. $A$, the hillshade method and $B$, the wavelet-transform method. 


\section{Considerations}

Several considerations for future efforts to identify levees from remotely sensed, high-resolution topographic data include the following:

1. The typical size of a levee differs, even for the same feature (for example, the top width of feature d-8 [fig. 3] ranges from approximately $1-7 \mathrm{~m}$ along its length).

2. The hillshade method will preferentially emphasize the linear features in the landscape that are perpendicular to the illumination source and can fail to identify those features aligned with the illumination source. Thus, the results from the wavelet analysis could help select the location of the illumination source for the hillshade analysis.

3. The top width of many levees was $3-5 \mathrm{~m}$, and the features were most prominently identified in the wavelet transform using a scale of 3 .

4. Construction practices may differ regionally, such as the use of ring levees or roadways serving as levees.

5. In urban areas, the topographic and imagery data sources can rapidly become outdated, which stresses the need for site visits, latest aerial imagery surveys, and updated topography.

6. Levee construction or enhancement has commonly taken place during or following large historical flood-fight activities. Historical research for future studies may be warranted to identify periods and locations of such construction episodes.

7. A global positioning system (GPS)-enabled camera and field notes of onsite observations help provide important documentation of identified features in the field.

\section{Limitations of Methods}

A limitation of both methods is that floodwalls are not apparent in bare-earth topography because the base- and topwidths frequently are less than the 1-m resolution of DEM data. Although the features can substantially affect flood flows, floodwalls would only be identified by field visits or from local knowledge of city managers. In some cases, floodwalls may be visible in aerial photography but would still require verification.

Although the wavelet-transform method provides more automation to highlight potential levee locations in comparison to the hillshade method, the wavelet-transform method still requires a knowledgeable person to review, interpret, and optimize the wavelet-transform coefficient results, topography, hillshades, transportation data, and aerial photographs in order to distinguish negligible features from potential levees or other structures that may affect flood flows.
For the methods to work, the cell size of the DEM must be smaller than the size of the features to be detected, and the vertical accuracy of the DEM needs to be finer than the height of features to be detected, which is generally the case for lidar-derived DEMs. Applying the methods to large areas might be difficult because lidar datasets commonly are large; thus, making the datasets difficult to download and process. The limitation is conditioned by present (2014) internet and computing speeds and data storage typically available to the image analyst, which differ greatly and could become negligible issues as technology advances. However, the limitation also may be overcome by using coarser topographic data or resampling the lidar data before processing.

\section{Future Advancements of Methods}

Identifying potential levees from remotely sensed, high-resolution topographic data in the office can streamline the assessment of undocumented levees across large areas. This pilot study tested two methods that, as complementary approaches, indicate the possibility of providing more rapid detection of undocumented levees in communities along rivers.

To further develop and more fully automate a geospatial tool for identifying potential levees, a few future advancements could be considered. The analysis for this pilot study used proprietary software for performing the wavelet transform; however, with knowledge of applications coding in a GIS, a programmer could enable the wavelet transform to be applied within the GIS environment. Resulting benefits may include relief from some required proprietary licenses and less transfer of information from outside the GIS. Also, if a general size for levees being searched for is presumed, then scaleparameter thresholds can be set at the initiation of the analysis that bound parameter optimization within a specific range of values and only the features that appear prominently across several different scales within the optimization could be kept. Finally, the wavelet-transform results could be analyzed by an expert system that would compare the identified features with other geographic information, such as roads, topographic feature layers (river banks, valley bluffs, canals, and ditches), or other infrastructure to more rapidly classify features identified by the wavelet transform.

\section{Summary}

Many undocumented and commonly unmaintained levees exist in the landscape limiting flood forecasting, risk management, and emergency response. This report describes a pilot study completed by the U.S. Geological Survey in cooperation with the U.S. Army Corps of Engineers to assess two methods to identify undocumented levees using remotely sensed, highresolution topographic data. For the first method, the U.S. Army Corps of Engineers examined hillshades computed from 
a digital elevation model to visually identify potential levees and then made a detailed site visit to assess the validity of the potential features. For the second method, The U.S. Geological Survey applied a wavelet transform to a digital elevation model to identify potential levees that may lead to more automated identification of levees. The hillshade method was applied to Delano, Minnesota, and the wavelet-transform method was applied to Delano and Springfield, Minnesota.

Both methods were successful in identifying levees but also identified other features that required interpretation to differentiate from levees such as constructed barriers, high banks, and bluffs. Some potential levees that were difficult to identify at first using the hillshade method were readily identified by the wavelet-transform method. However, some potential levees identified by the hillshade method were only identified by the wavelet-transform method using certain scales and were more difficult to identify at larger scales because of the small spatial extent of the levees. Characteristics of the potential levees were presented to demonstrate the typical size of levees analyzed in this pilot study.

The two methods assessed in this study are complementary to each other. To identify potential levees for field verifications, using the hillshade method in conjunction with the wavelet-transform method would provide more reliable results more efficiently. A potential approach for future applications may be to (1) use the wavelet-transform method to rapidly identify potential levees, (2) further examine topographic data using hillshades and aerial photos to classify each feature, and (3) check each identified potential levee with local managers and field visits.

\section{References Cited}

Addison, P.S., 2002, The illustrated wavelet transform handbook-Introductory theory and applications in science, engineering, medicine and finance: Philadelphia, Pa., Institute of Physics Publishing, 353 p.

Bolton and Menk, Inc., 2011, City of Springfield feasibility report-Reconstruction of the levee between Cass Avenue and C.S.A.H. No. 5 in Springfield, Minnesota: Mankato, Minn., Bolton and Menk, Inc.

Esri, 2014, ArcGIS Help 10.1, Hillshade function: accessed August 3, 2014, at http://resources.arcgis.com/en/help/ main/10.1/index.html\#//009t0000004z000000.

Kumar, P., and Foufoula-Georgiou, E., 1994, Wavelet analysis in geophysics - An introduction, in Foufoula-Gerogiou, E., and Kumar P., eds, Wavelets in geophysics - Wavelet analysis and its applications, v. 4: San Diego, Calif., Academic Press, Inc., p. 1-43.
Lashermes, B., Foufoula-Georgiou, E., and Dietrich, W.E., 2007, Channel network extraction from high resolution topography using wavelets: Geophysical Research Letters, v. 34, no. 23. [Also available at http://dx.doi. org/10.1029/2007GL031140.]

Minnesota Geospatial Information Office, 2012, Minnesota LiDAR Research and Education Subcommittee-Glossary of LiDAR-related terms: accessed February 25, 2014, at http:/www.mngeo.state.mn.us/committee/elevation/ research_education/MnLiDARGlossary.pdf.

Minnesota Geospatial Information Office, 2014, LiDAR Elevation Data for Minnesota: accessed August 3, 2014, at http://www.mngeo.state.mn.us/chouse/elevation/LiDAR. html.

National Weather Service, Advanced Hydrologic Prediction Service, 2014a, Crow River at Delano: accessed October 2, 2014, at http://water.weather.gov/ahps2/hydrograph. php wfo $=$ mpx\&gage $=$ DELM5.

National Weather Service, Advanced Hydrologic Prediction Service, 2014b, Cottonwood River (MN) above Springfield: accessed October 2, 2014, at http://water.weather.gov/ ahps $2 /$ hydrograph.php?wfo=mpx\&gage $=$ SPFM5.

U.S. Army Corps of Engineers, 2014, National Levee Database: accessed July 30, 2014, at http://nld.usace.army.mil. 
Publishing support provided by:

Rolla Publishing Service Center

For more information concerning this publication, contact: Director, USGS Minnesota Water Science Center 2280 Woodale Drive

Mounds View, Minnesota 55112

(763) 783-3100

Or visit the Minnesota Water Science Center Web site at: http://mn.water.usgs.gov/ 

